\title{
The Effectiveness of Reality Therapy Based on Choice Theory on Marital Intimacy and Sexual Satisfaction of Newly Married Women
}

\author{
Afsun Farhadi ${ }^{1}$, Shahrbanoo Salehin ${ }^{2 *}$, Shahrokh Aghayan ${ }^{3}$, Afsaneh Keramat ${ }^{4}$, Solmaz Talebi $^{5}$ \\ 1. MSc Student of Midwifery Counseling, School of Nursing and Midwifery, Shahroud University of Medical Sciences, \\ Shahroud, Iran \\ 2. Assistant Professor, Department of Reproductive Health, School of Nursing and Midwifery, Shahroud University of \\ Medical Sciences, Semnan, Iran \\ 3. Assistant Professor, Behavioral and Social Sciences Research Center in Health, Shahroud University of Medical \\ Sciences, Shahroud, Iran (Corresponding Author) \\ 4. Professor, Department of Reproductive Health, Center for Research on Women's Health and Fertility, Shahroud \\ University of Medical Sciences, Shahroud, Iran \\ 5. Assistant Professor, Department of Epidemiology, School of Health, Shahroud University of Medical Sciences, \\ Shahroud, Iran
}

Article Info

Received: 2020/02/18;

Accepted: 2020/03/09;

Published Online: 2020/06/24

10.30699/ajnmc.28.2.83

Original Article

Use your device to scan and read the article online

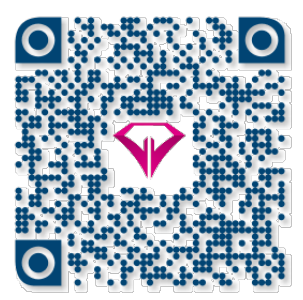

\section{ABSTRACT}

Introduction: Considering the necessity of providing required education to newly married couples, the present study aimed at investigating the impact of reality therapy-based choice theory training on marital intimacy and sexual satisfaction of newly married women in Ardabil city, Iran.

Methods: This research is a Randomized clinical trial. Totally 5 out of 14 medical centers were selected by simple, random sampling method in Ardabil city, Iran. Once the required permissions, questionnaires and research ethics were obtained and the target population was determined, researchers provided the women visiting the medical centers with Intimacy Scale and Sexual Satisfaction Questionnaire. Then, 70 individuals who underscored the cut point were included in the research. Thompson and Walker Intimacy Scale and Sexual Satisfaction Questionnaire were two research tools in this contribution. Data were analyzed using repeated measure analysis of variance with SPSS 22 software.

Results: Results of the repeated measures analysis of variance demonstrated that there was no significant difference between experimental and control groups in sexual satisfaction and marital intimacy in pre-test stage. In post-test and follow-up stages, there was a significant difference between the two groups in sexual satisfaction and marital intimacy $(P<0.001)$.

Conclusion: Therefore, according to the findings of this study and its comparison with the existing research literature in this field, it can be concluded that the theory of selection theory helps newlyweds by improving the relationship between couples and increasing the infertility of couples so that they can be real without feeling controlled and controlled.

Keywords: Reality therapy, choice theory, Marital intimacy, Sexual satisfaction, Newly married women

Corresponding Information:

Shahrbanoo Salehin, Assistant Professor, Department of Reproductive Health, School of Nursing and Midwifery, Shahroud University of Medical Sciences, Semnan, Iran. Email: drbsalehin@gmail.com

Copyright $(2020$, This is an original open-access article distributed under the terms of the Creative Commons Attribution-noncommercial 4.0 International License which permits copy and redistribution of the material just in noncommercial usages with proper citation.

How to Cite This Article:

Farhadi A, Salehin S, Aghayan S, Keramat A, Talebi S. The Effectiveness of Reality Therapy Based on Choice Theory on Marital Intimacy and Sexual Satisfaction of Newly Married Women. Avicenna J Nurs Midwifery Care. 2020; 28 (2) 
اثربخشى واقعيتدرمانى مبتنى بر نظريةٌ انتخاب بر صميمت زناشويى و رضايت جنسى زنان تازهمتأهل افسون فرهادى'، شهربانو صالحين ז"، شاهرخ آقايان"، افسانه كرامت"، سولماز طالبىهـ

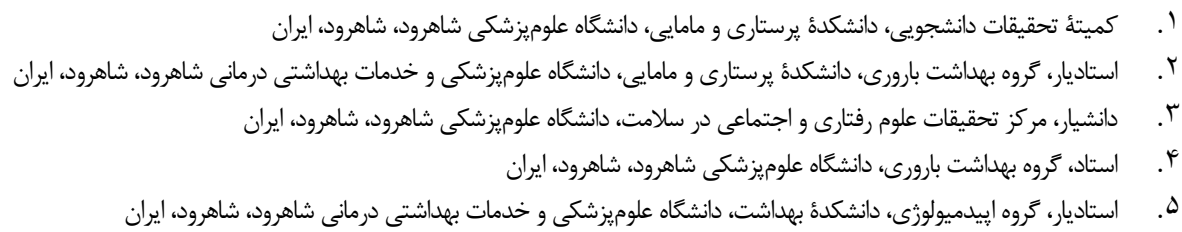

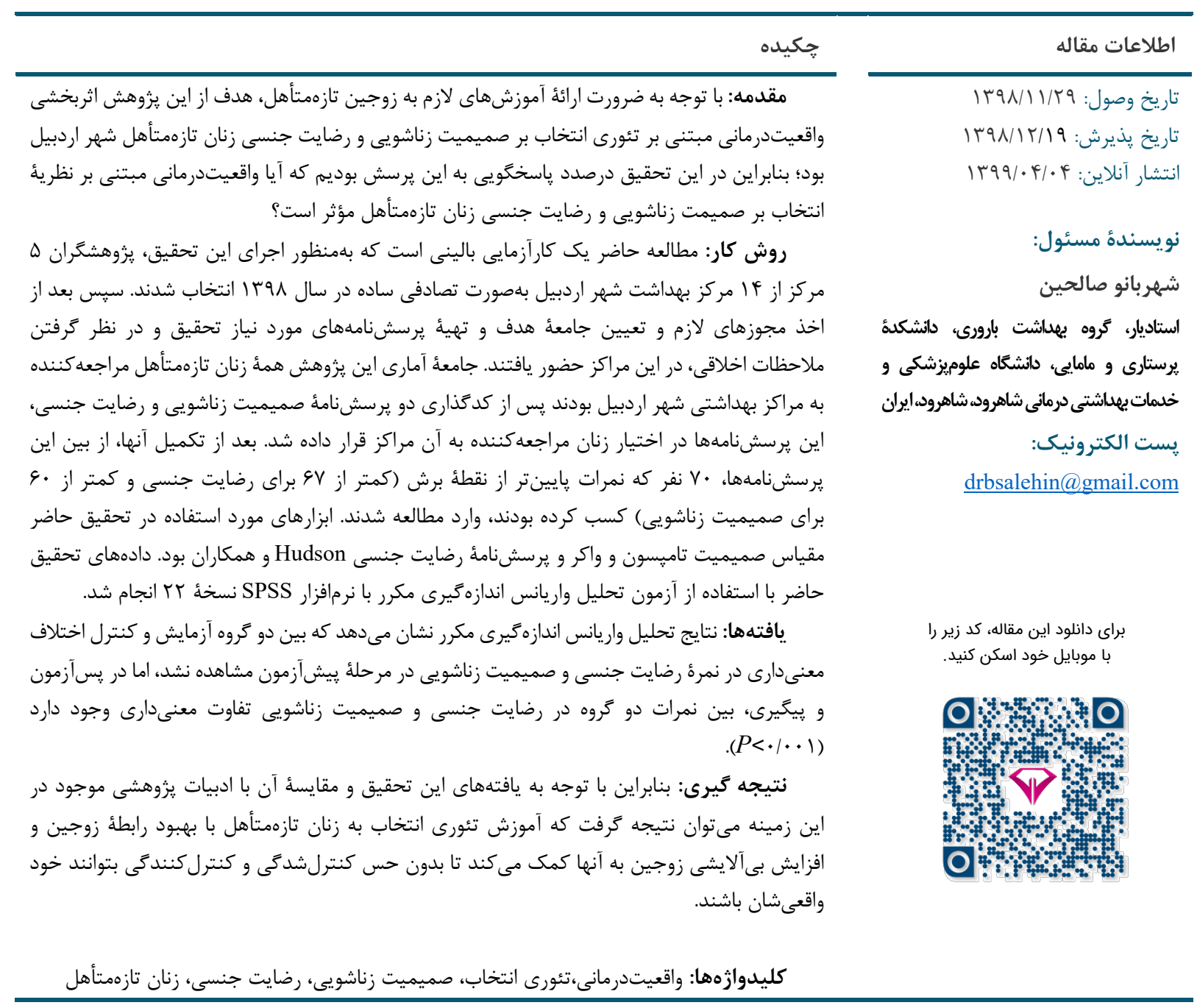

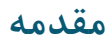

جنبههاى اصلى ازدواج كه نيازمند توجه ويزٔه زوجين و مشاوران خانواده است، صميمت ميان زوجين است.

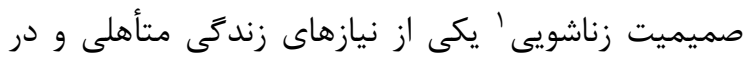

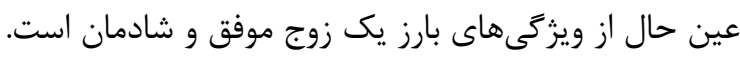

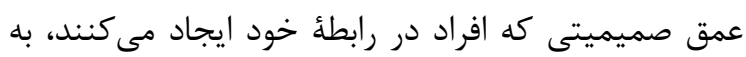

ازدواج بلمنزلؤ مهمترين و عالىترين رسم اجتماعى، براى دستيابى به نيازهاى عاطفى افراد همواره مورد تأكيد

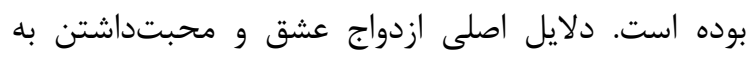

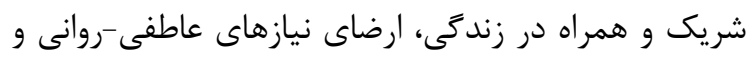

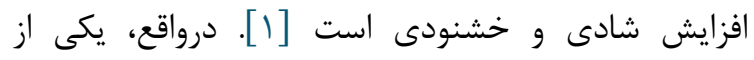

1. Marital intimacy 
سلامت فرد مىانجامد و همجنين در ارتقاى شغلى، توانمندى و خلاقيت شخص، خلل وارد مى كندرضايت جنسى در واقع ياسخى عاطفى برخاسته از ارزشيابى ذهنى

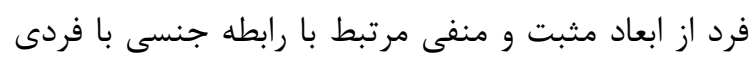

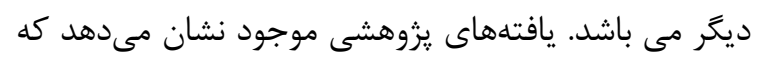

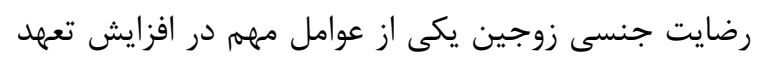

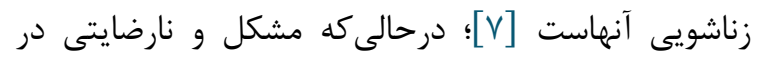
رابطهٔ جنسى زوجين نهتنها مىتواند كيفيت رابطؤ زناشويى دائى

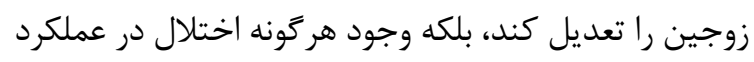

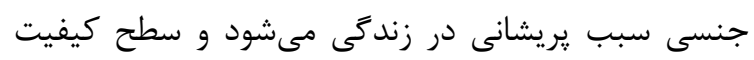
زندگى را در افراد كاهش مى ندهد [1]].

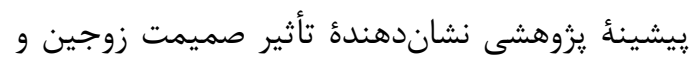

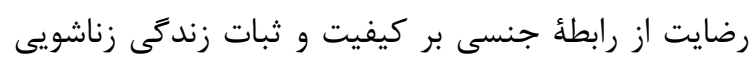

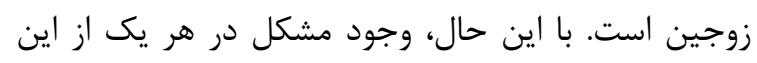

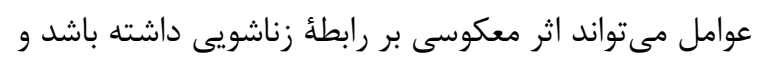

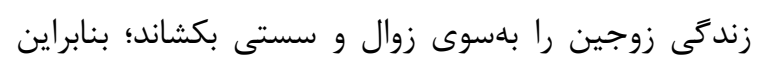

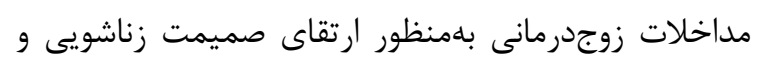

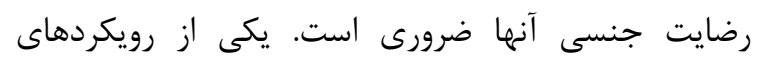

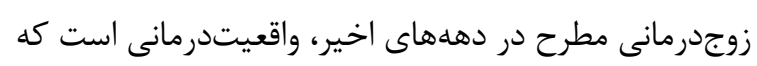

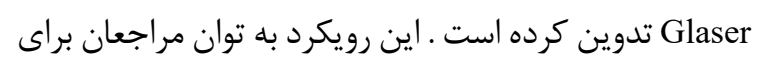

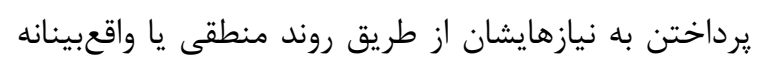

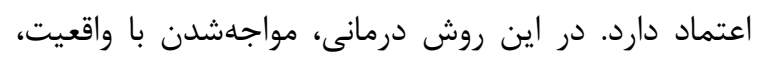

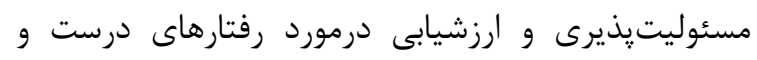

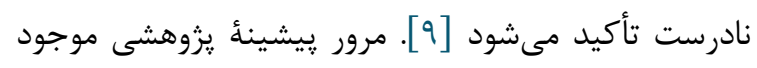

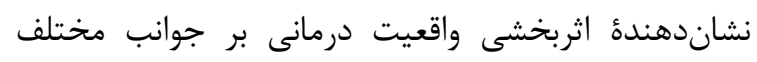

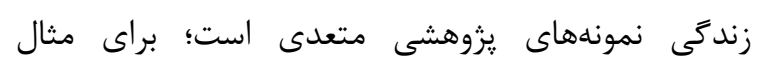
Marshall وWeisner

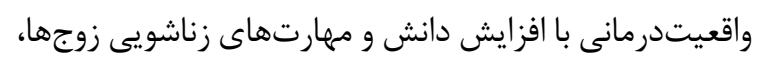

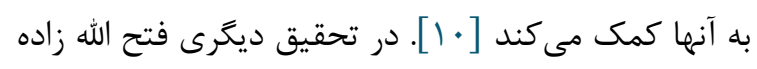

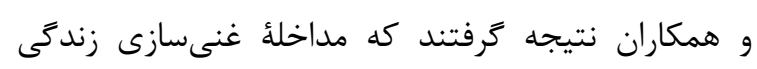

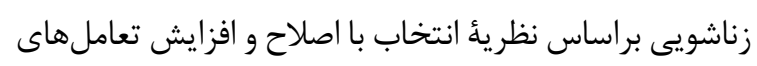

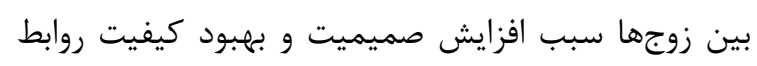

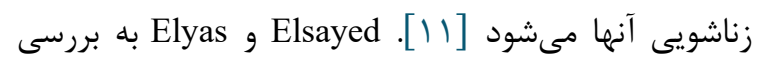

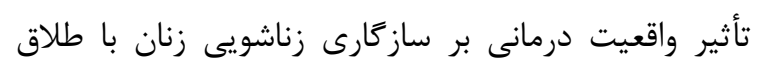

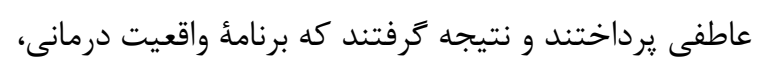

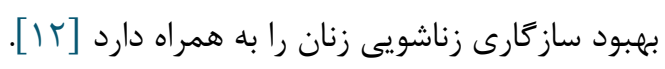

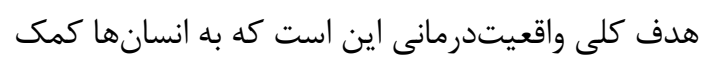

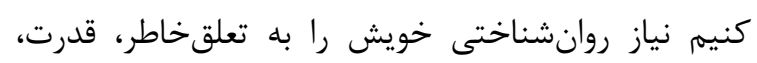

ميزان بسيارى به توانايى آنها براى ارتباط دقيق، مؤثر و

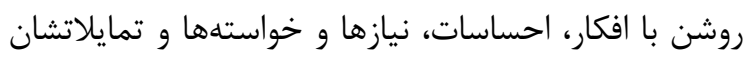

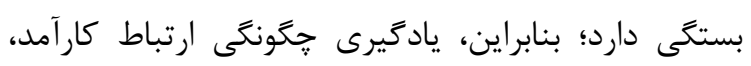

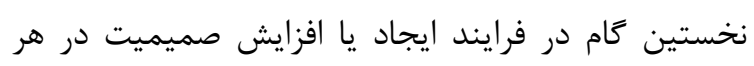
رابطهاى است [r]]. صميميت فرايندى تعاملى است كه شامل ابعاد مرتبط است. همجنين يك نياز واقعى و ريشهدار انسان

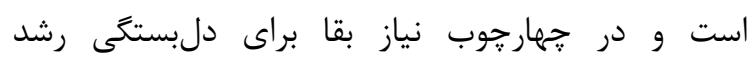
مى كند. Bagarozzi صميميت را نزديكى، تشابه و روابطئ

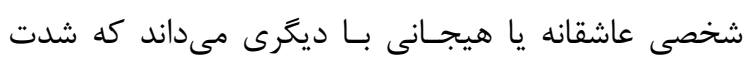

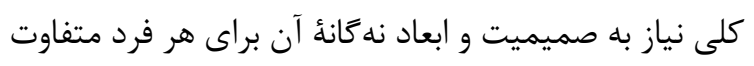

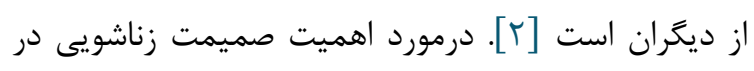

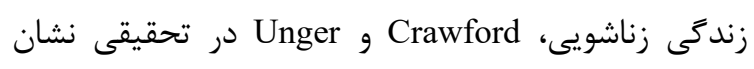

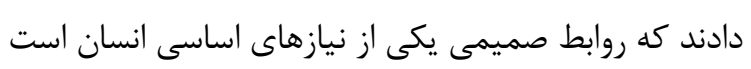

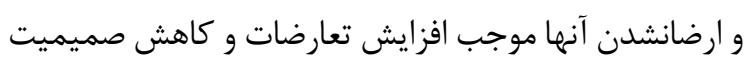

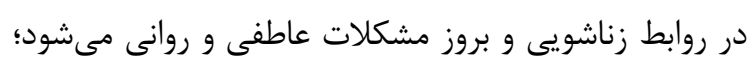

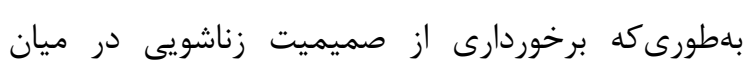

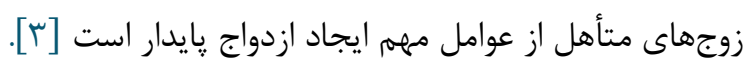

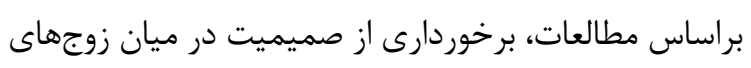

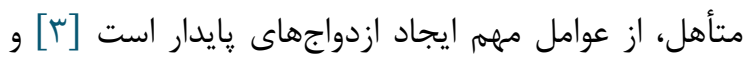

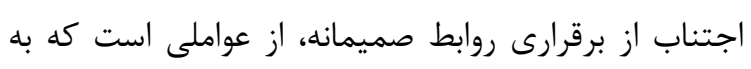

شكست در زندگى خانوادگى مى رانجامد [ب].

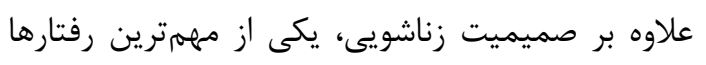

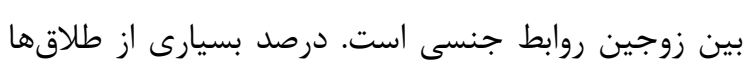
بلهدليل ناتوانى در كميت و كيفيت رابطؤ جنسى بين زوجين إنسين

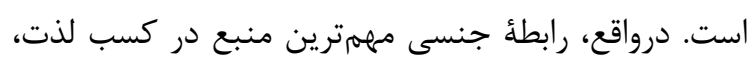

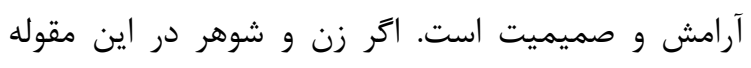
بتوانند براى يكديكر ايجاد لذت و آرامش كنند و و درواقع، به آنه

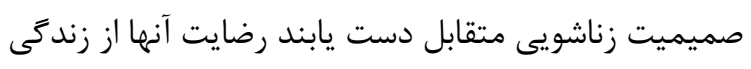
بيشتر مىشود و احساس فرسودىى زناشويى ميان آنها

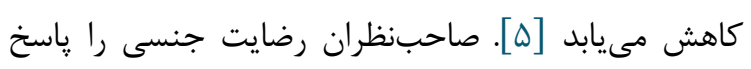

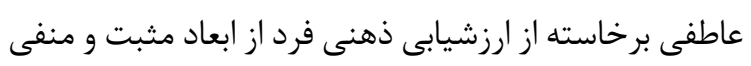

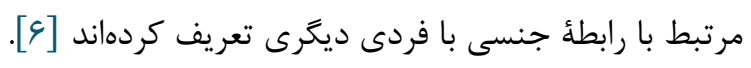
مفهوم رضايت جنسى به دو صورت است: رضايت از فعاليت

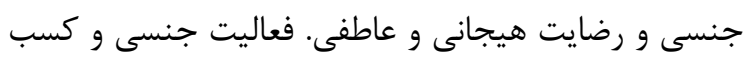

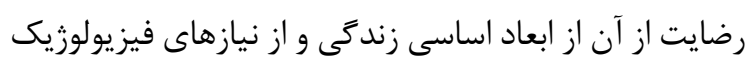

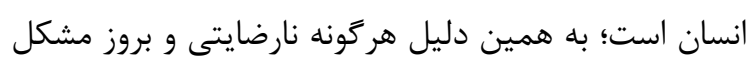

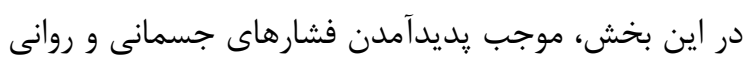

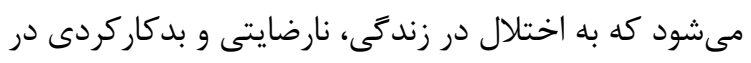


ع ا ثربخشى واقعيتدرمانى مبتنى بر نظريئ انتخاب بر صميمت زناشويى

زناشويى) كسب كرده بودند، وارد مطالعه شدند و بلطور

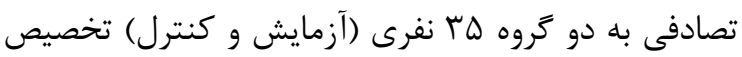

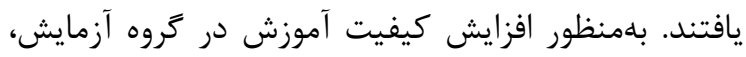

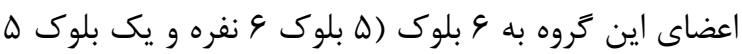

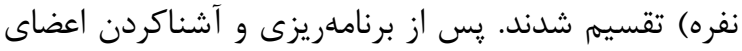

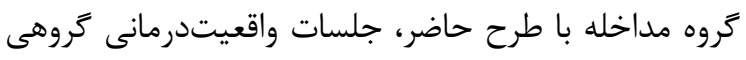

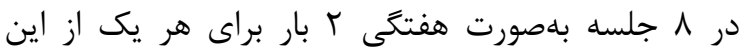

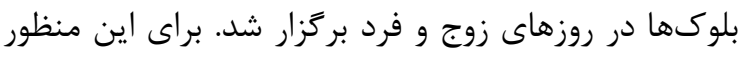

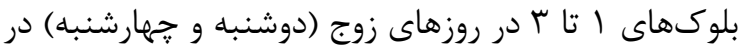

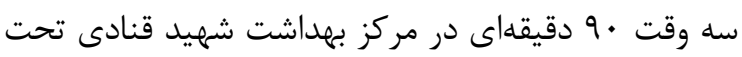

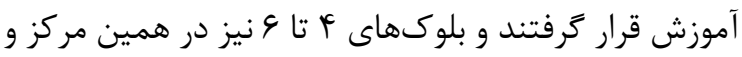
در روزهاى فرد (سهشنبه و وينجشنبه) تحت آموزش

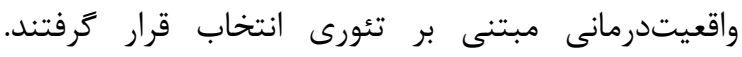
درنهايت، يس از كذشت يك هفته و يك ماه از اتمام جلسات، براساس هماهنكَىهاى قبلى با شركت كنندَان، در زمان و

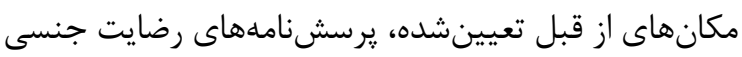

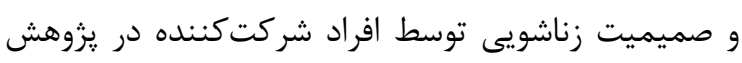

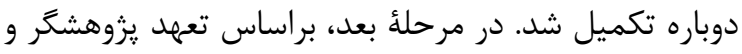

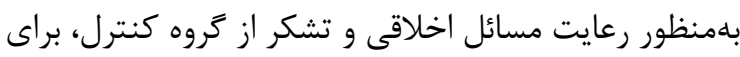

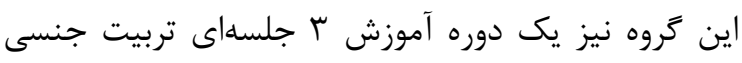

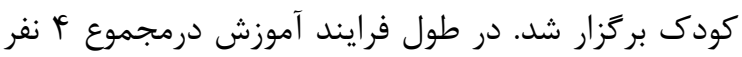

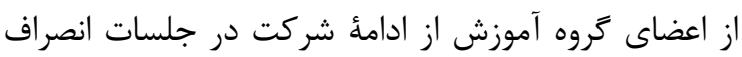

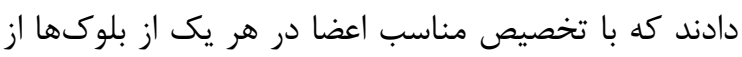
متناسبنبودن بلوكها ممانعت شد؛ زيرا يكى از از راههاى

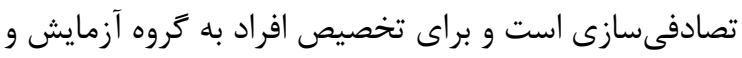

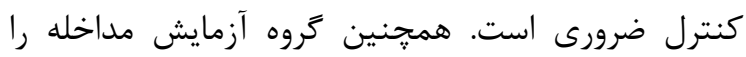

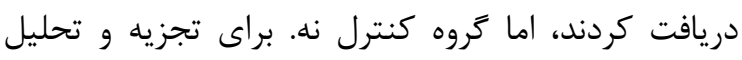

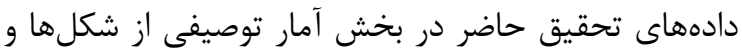

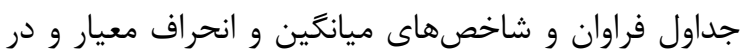

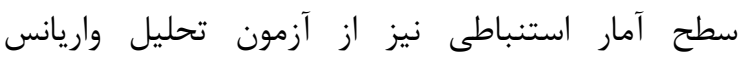
اندازهكيرى مكرر براى آزمون فرضيههاى يزوهش استفاري آزادي

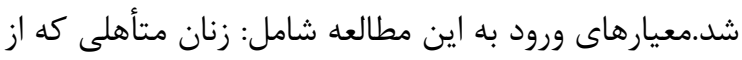
زندگى در خانهٔ مشترك با همسر اول آنها بيش از

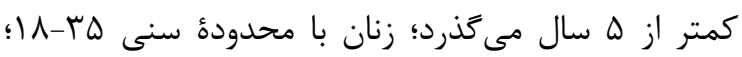

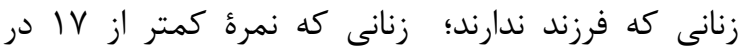

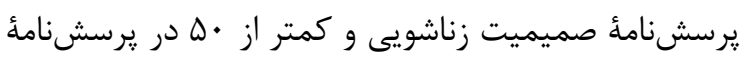

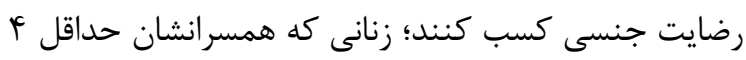

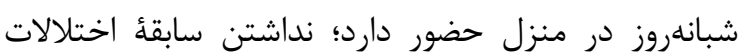

آزادى و تفريح مسئولانه و به نحو رضايتبخشى ارضا كنند.

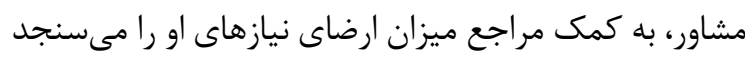
و مشخص مى كند كه براى ارضاى اين نيازها بايد جهان ارضه

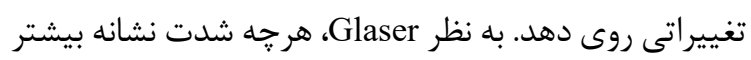

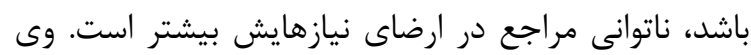

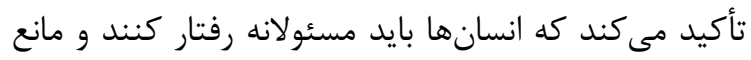

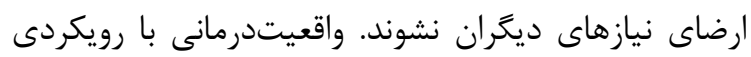

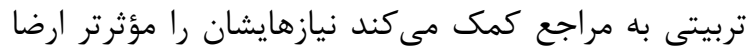

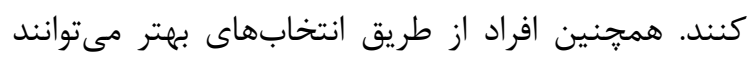

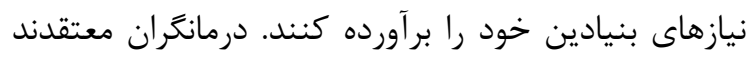

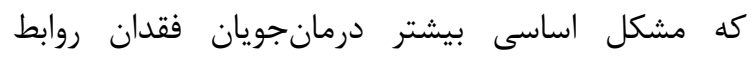

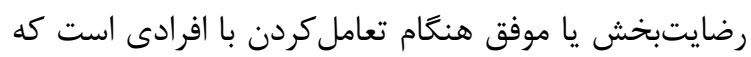

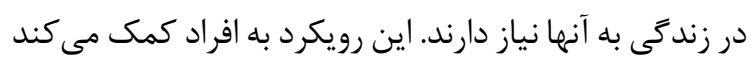

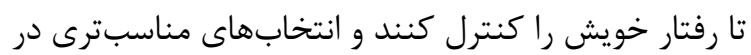
زندكى شان داشته باشند. با توجه اهميت صميميت زناشويى

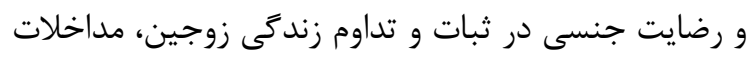

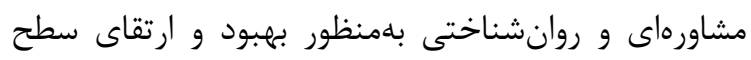

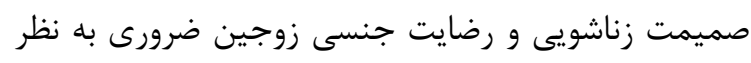

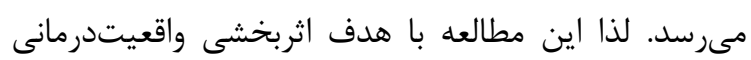

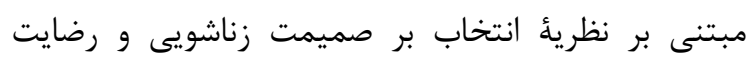
جنسى زنان تازممتأهل انجام شد.

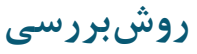

اين مطالعه يك كارآزمايى بالينى است كه بلمنظور

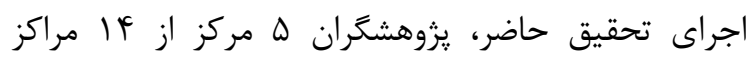
بهداشت شهر اردبيل بهصورت تصادفى انتخاب شدند كه يس تران از دريافت مجوزهاى لازم و تعيين جامعأه هدف، همجنين

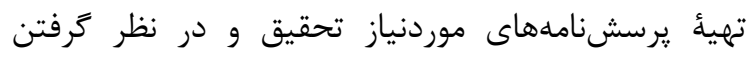

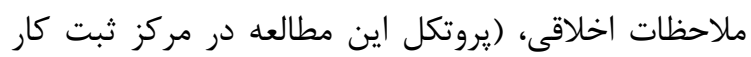

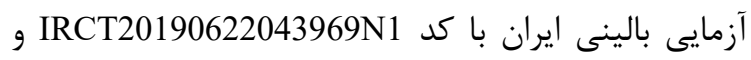

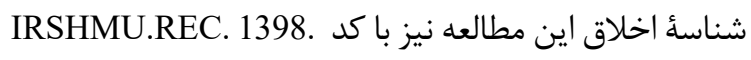
028 دانشعاه علوميزشكى شاهرود تأييد شد)، در اين مراكز

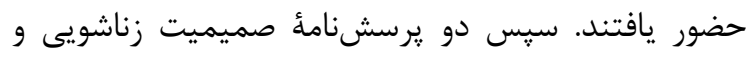

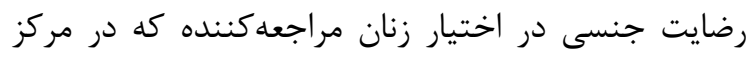

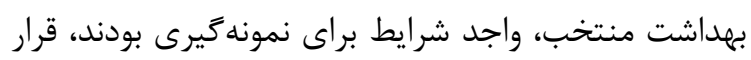
داده شد. از ميان اين يرسشنامههاى ياسخدادهده، • • نفر

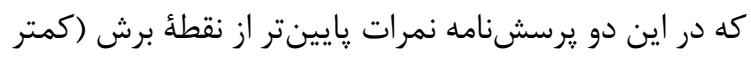
از \&V براى رضايت جنسى و كمتر از •و براى صميميت 
يرسشنامه ب9/ • بود [0 10]. برسشنامه بومى شده و قبلاً روا

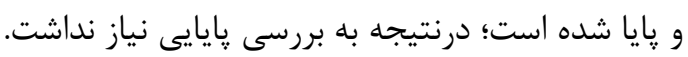

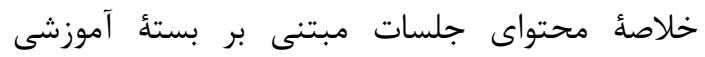
واقعيتدرمانى براى زوجين براساس استاندارد تأييدشدة مؤسسه Glaser به قرار زير است:

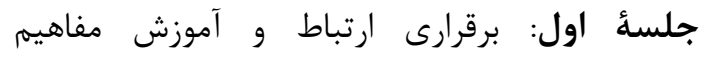

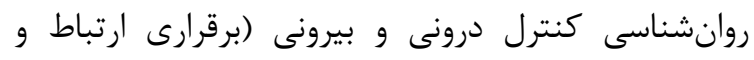

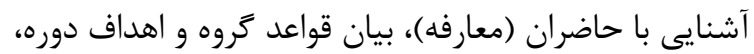
طرح سؤالات اساسى، آشنايى با اصول نظرئٔ انتخاب و وران

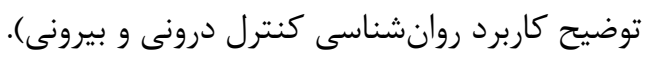

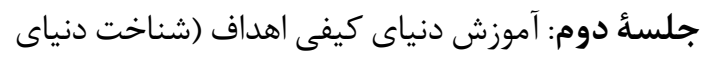
كيفى و تصاوير درون آن و ارزيابى و سنجش دنياى كيفى). جلسهُ سوم: آموزش هفت عادت مخرب ان ازدواج (ارزيابى

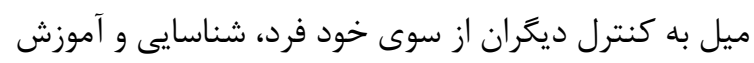

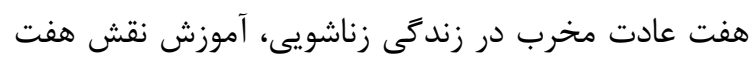
عادت مخرب در روابط زناشويى).

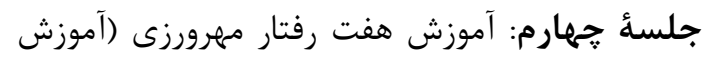

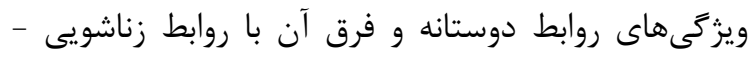

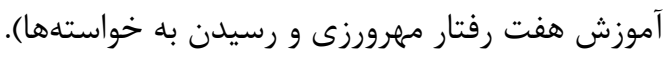

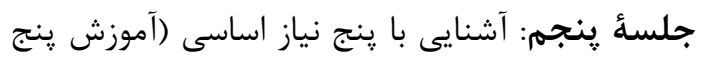

نياز اساسى، كمك به افراد براى درك نيازهاى اساسى).

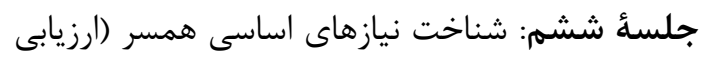

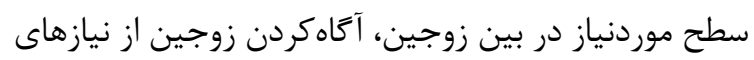

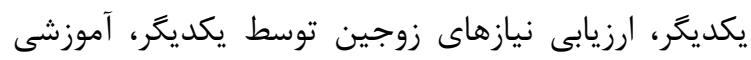
تفاوت نيازها در زوجين). جلسهٔ هفتم: شناخت دايرءٔ حل (آموزش دايرة فرضى نائ

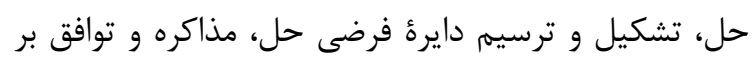
سر نحوة ارضاى نيازها). جلسةٔ هشتم: ارزيابى دايرٔ حل و اخذ پِّآزمون (ارزيابى دايرٔ حل صورتگرفته، انجام دايرٔٔ حل در جلسة مشاوره براى

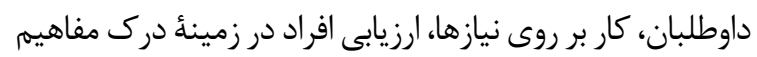

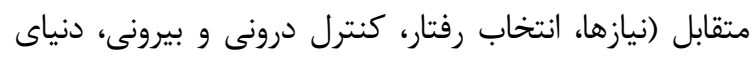
كيفى)، جمعبندى و نتيجه گيرى نهايى با زنان تازمتأهل، ارائه يس از آزمون، تشكر و خداحافظى).

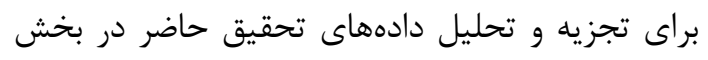

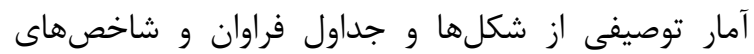

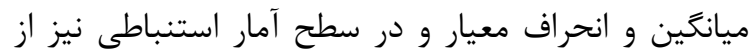

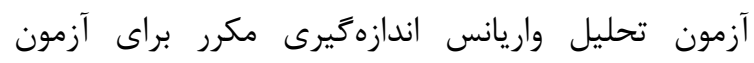

روانى و جسمانى شديد؛ توانايى خواندن و نوشتن به زبان فارسى بود. هم جنين معيار هاى خروج از از مطالعه شامل:

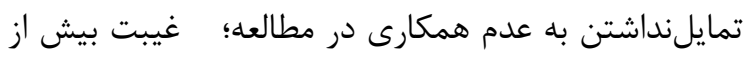

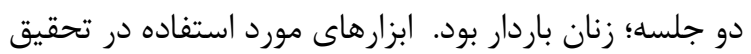
حاضر مقياس صميميت تاميسون و واكر و ترسشنامئ رضايت جنسى Hudson و همكاران بود.

\section{يرسشنامئ صميميت Walker و}

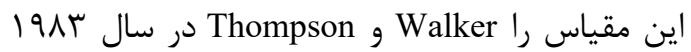
ساختند كه IV يرسش دارد و براى سنجيدن ميزان

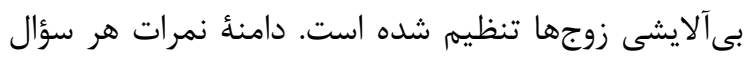

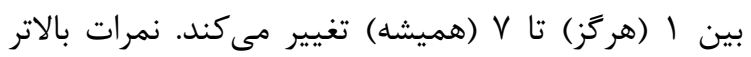

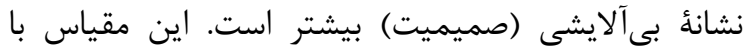

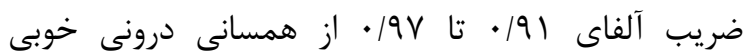

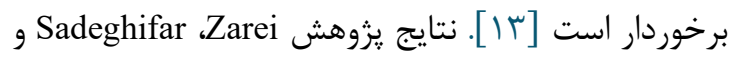

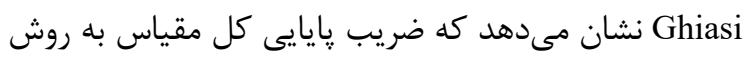

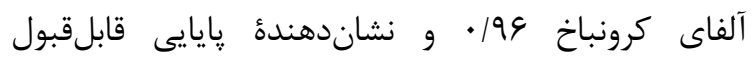

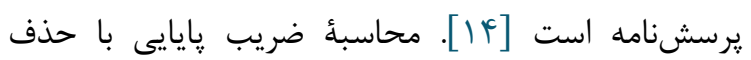

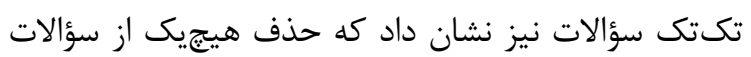

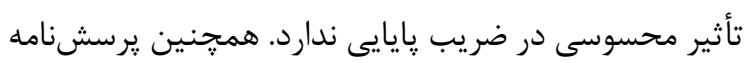

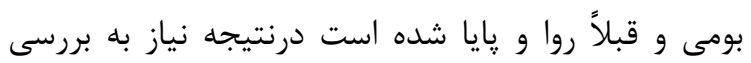

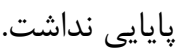

\section{يرسشنامة رضايت جنسى}

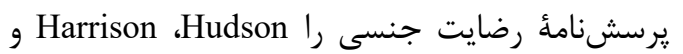
Crosscup

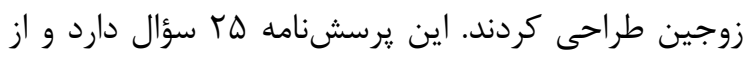

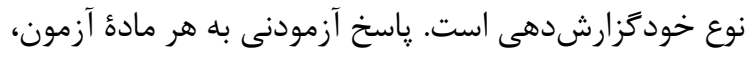
در سطح يك مقياس V درجهاى بين صفر تا 9 مشخص

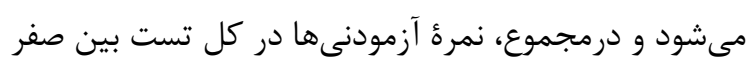

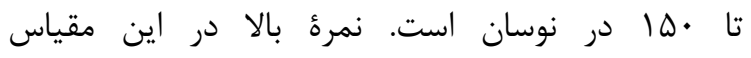

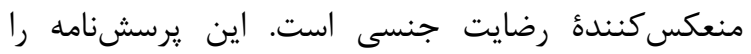

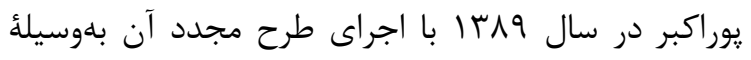

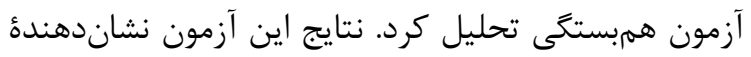

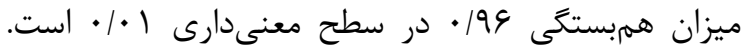

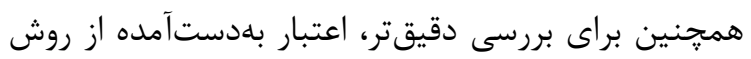

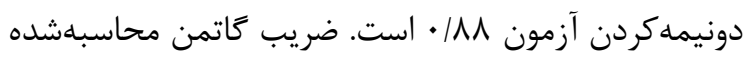

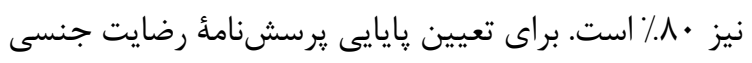

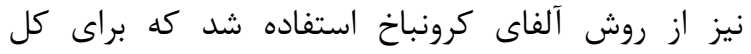


M اثربخشى واقعيتدرمانى مبتنى بر نظرية انتخاب بر صميمت زناشويى

و در گروه كنترل بلترتيب سF/AY و Q

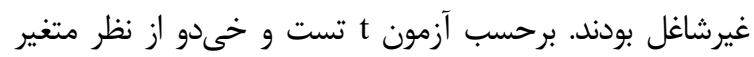

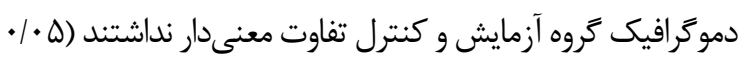
P> يسآزمون و پييگيرى گروه آزمايش و كنترل آمده است. در جدول ا، ميانگين و انحراف معيار نمرات صميميت

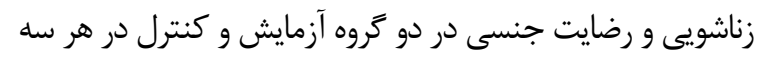

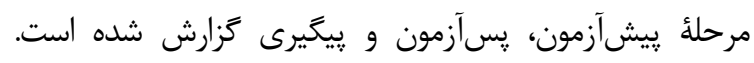

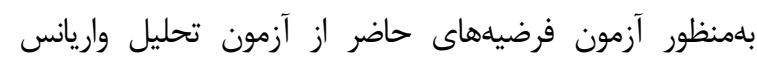

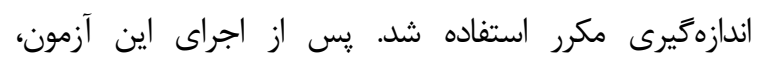

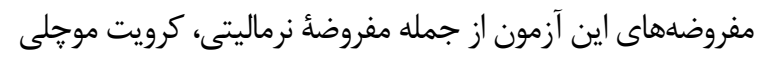

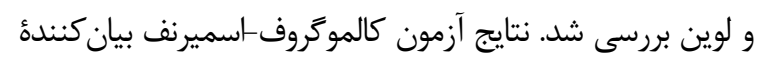

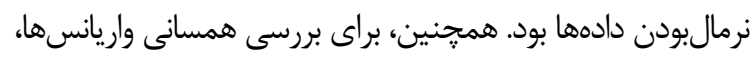

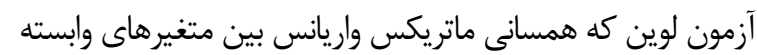
در بين گروههاى متغير مستقل را نشان مى دهد، براى متغيرهاى ماني

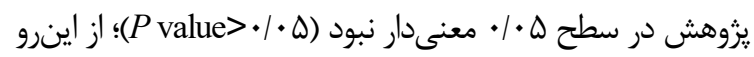
شرط همگنى واريانس-كوواريانس بلهدرتى رعايت شده است.
فرضيههاى روهش استفاده شد. دادههاى حاصل از

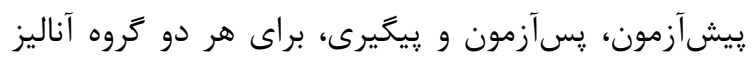

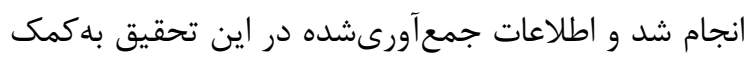
SPSS Inc., Chicago, ) نسخاف كافزار آمارى SPSS تجزيه و تحليل شد. در اين تحقيق ملاحظات (Ill., USA اخلاقى مانند كسب رضايت آكاهانٔ شركت كنندگان در يزوهش با بيان اهداف تحقيق و محرمانگى مشخصات شركت كنندگًان در تحقيق رعايت شد.

\section{يافته ها}

يافتههاى دموگرافيك شركت كنندگان در دو گروه آزمايش و كنترل نشان مىدهد كه شركتكنند تحصيلات در سه مقطع زير دييلم و دييلم، كارشناسى و كارشناسى

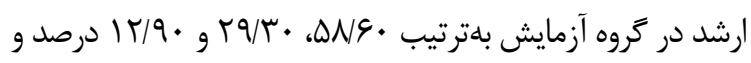

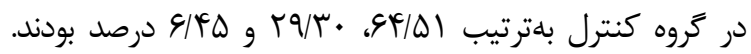

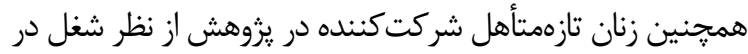

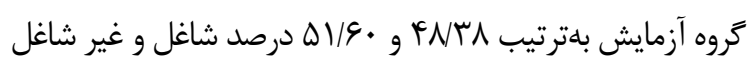

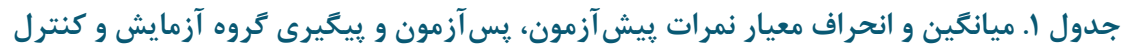

\begin{tabular}{|c|c|c|c|c|c|}
\hline \multicolumn{2}{|c|}{ كروه كنترل } & \multicolumn{2}{|c|}{ تروه آزمايش } & \multirow{2}{*}{ 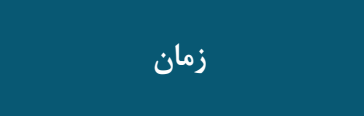 } & \multirow{2}{*}{ 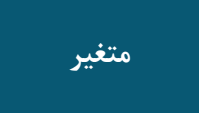 } \\
\hline انحراف معيار & ميانگَين & انحراف معيار & ميانگَين & & \\
\hline$\Delta / \Psi^{+}$ & $p q / 4 F$ & $F / l r$ & $\Delta T / F \Delta$ & ي يشآزمون & \multirow{3}{*}{ صميميت زناشويى } \\
\hline$\Delta / \Delta \Delta$ & FN/QG & $\Delta / \cdot G$ & $V \backslash / \Lambda I$ & يسآزمون (ا هفته پֶ از مداخله) & \\
\hline 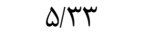 & $\mid\langle N / F|$ & $g / V^{F}$ & $V F / 19$ & يِيخيرى (ا ما پس مداخله) & \\
\hline $\mathrm{V} / \mathrm{Vq}$ & GT/TY & $V / \Delta \varphi$ & sY/Ts & 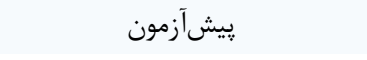 & \multirow{3}{*}{ 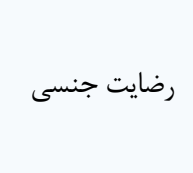 } \\
\hline$N / \cdot$ & GI/4F & $N \cdot F$ & $\Lambda \mu / q \mu$ & ֶِ آزمون (1 هفته پِ از مداخله) & \\
\hline$N \cdot r$ & 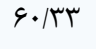 & N/qF & $\Lambda F / T V$ & يِيَيرى ( ماه پِ از مداخلة) & \\
\hline
\end{tabular}

در يكى از مراحل در درون زروه با بقيهٔ مراحل تفاوت وجود

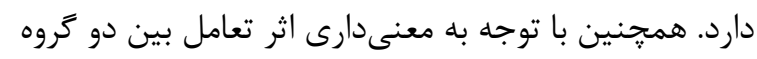

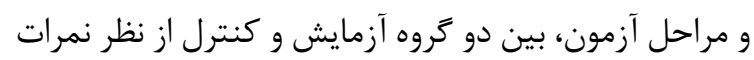

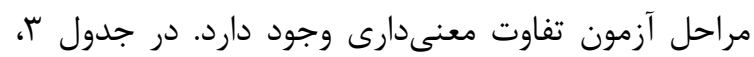

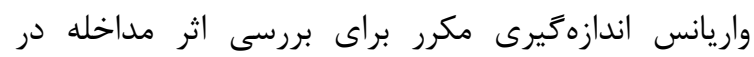
صميميت زناشويى بررسى شده است.
براى بررسى همخَنى واريانسهاى درونگروهى از آزمون كرويت موجلى استفاده شد كه با توجه به نتايج بهدست آمده، آزمون

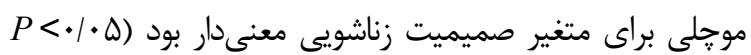
value). در جدول r، نتايج تحليل واريانس آمده است. جدول r نشان مىدهد آزمون ويكلز حاكى از تفاوت معنى دار درون گروهى در مراحل مختلف است؛ يعنى حداقل جدول r. نتايج تحليل واريانس

\begin{tabular}{|c|c|c|c|c|c|c|}
\hline Sig & خطا df & فرضيه df & $\mathbf{F}$ & مقار & & \\
\hline$\cdot 1 \cdot \cdot 1$ & $\Delta q \cdots$ & $r / \cdots$ & $1 / T V$ & $\cdot / 1 \wedge \vee$ & ل لامبداى ويكلز & اثر مراحل آزمون \\
\hline$\cdot / \cdot \cdot 1$ & $\Delta q \cdots$ & $r / \cdots$ & $1 / \Delta \Lambda$ & $\cdot / 1 \Delta V$ & لامبداى ويكلز & اثر تعامل (كروهم* مراحل) \\
\hline
\end{tabular}


جدول س. تحليل واريانس اندازهيرى مكرر براى بررسى اثر مداخله در صميميت زناشويى

\begin{tabular}{|c|c|c|c|c|c|}
\hline معنى دارى & $\mathrm{F}$ & ميانكين مجذورات & درجهُ آزادى & مجموع مجذورات & منبع \\
\hline$\cdot / \cdot 1$ & 199/4 & TIONTI & $1 / \pi 1$ & $T T \Delta T / \cdot V$ & اثر مراحل درونَّروهى \\
\hline.$/ \cdot 1$ & TUM/TI & rGVG/F. & $1 / \Gamma 1$ & FATGIIF & ثر تعامل (كروه** مراحل) \\
\hline
\end{tabular}

كنترل در مراحل پسآزمون و يیيَيرى باهم متفاوت هستند و اين تفاوت در متغير صميميت زناشويى به نفع گروه آزمايش است؛ بنابراين فرض يزوهش مبنى بر اثربخشى واقعيت درمانى بر صميميت زناشويى تأييد مىشود. در جدولهاى أ و ها آزمون تحليل واريانس و اندازمكيرى مجدد براى نشاندادن اثر واقعيتدرمانى بر رضايت جنسى آمده است.
تحليل فوق نشان مى دهد با تأكيد بر مقدار F بلدست آمده در

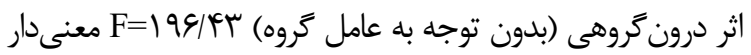
است؛ يعنى متغير صميميت زناشويى در مراحل مختلف نمرات

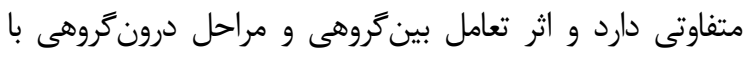

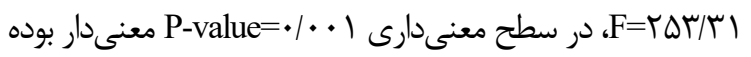

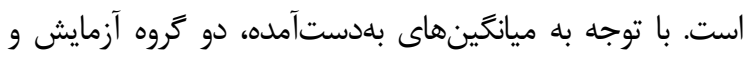

جدول F. نتايج تحليل واريانس

\begin{tabular}{|c|c|c|c|c|c|c|}
\hline Sig & خطا df & فرضيه df & $\mathbf{F}$ & مقدار & & \\
\hline$\cdot 1 \cdot \cdot 1$ & $\Delta q / \cdots$ & $r / \cdots$ & $1 / \cdot 1$ & $\cdot$ ITTS & لامبداى ويكلز & اثر مراحل آزمون \\
\hline$\cdot 1 \cdot \cdot 1$ & $\Delta q / \cdots$ & $r / \cdots$ & $1 / 49$ & $\cdot / / \vee \Delta$ & لامبداى ويكلز & اثر تعامل (كروه** مراحل) \\
\hline
\end{tabular}

جدول ه. تحليل واريانس اندازهَيرى مكرر براى بررسى اثر مداخله در رضايت جنسى

\begin{tabular}{|c|c|c|c|c|c|}
\hline معنى دارى & $\mathbf{F}$ & ميانتين مجذورات & درجهُ آزادى & مجموع مجذورات & منبع \\
\hline$\cdot 1 \cdot \cdot 1$ & $|V \varepsilon| \cdot F$ & 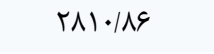 & I/TV & 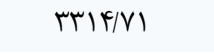 & اثر مراحل درونگروهى \\
\hline $.1 \cdot 1$ & TFNAF & एद9./9T & $1 / T V$ & FENF/DF & اثر تعامل (كروه** مراحل) \\
\hline
\end{tabular}

تعقيبى بنفرونى و توجه به ميانگينها نشان مىدهد كه صميميت زناشويى و رضايت جنسى در مراحل مختلف آزمون

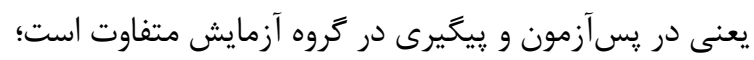

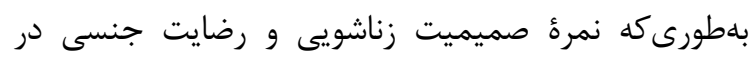

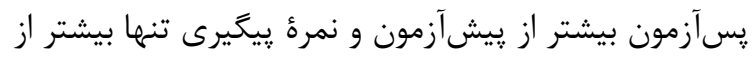

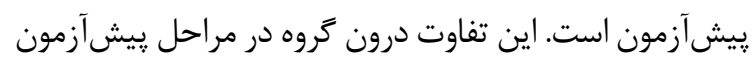

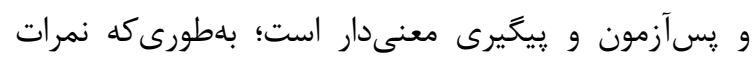

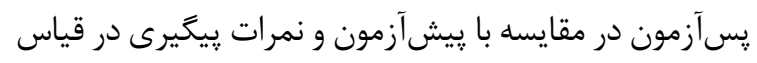

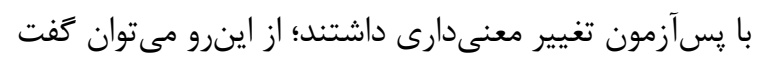

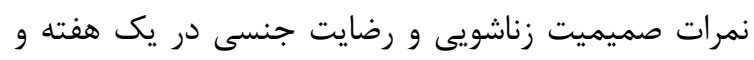
يك ماه يس از مداخله روند صعودى داشت.

\section{بحث}

تحقيق حاضر با هدف مطالعهُ اثربخشى واقعيت درمانى مبتنى بر نظريأ انتخاب بر صميمت زناشويى و رضايت جنسى نانى زنان تازهمتأهل صورت گرفت. يافتههاى تجزيه و و تحليل دادههاى بdدستآمده از تحقيق حاضر اين فرضيه را تأييد مى كند كه ميانگين نمرة صميميت زناشويى زنان تازهمتأهل در
جدول \& نشان مىدهد آزمون ويكلز حاكى از تفاوت معنىدار درون گروهى در مراحل مختلف است؛ يعنى حداقل در يكى از

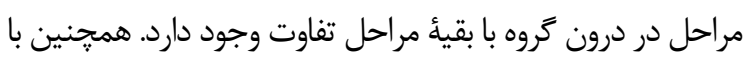

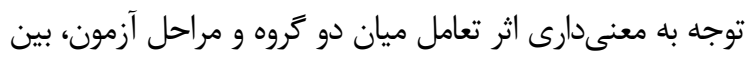

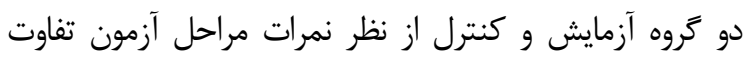

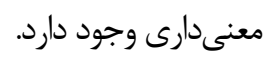
با توجه به جدول ه و با تأكيد بر مقدار F بهدستآمده در اثر درون

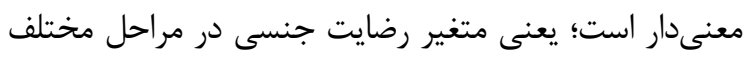

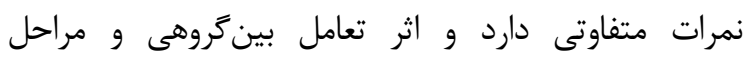
درون معنى P-value=

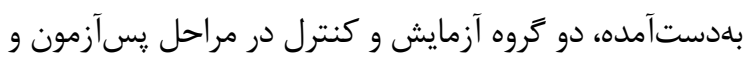

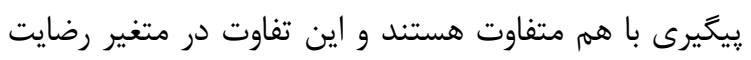

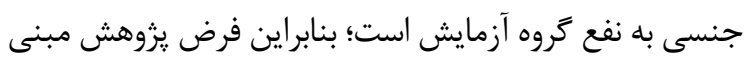
بر اثربخشى واقعيت درمانى بر رضايت جنسى تأييد مىشود.

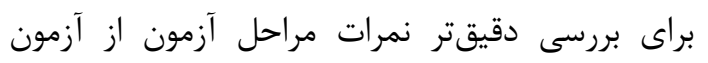
تعقيبى بنفرونى استفاده شد. يافتههاى حاصل از آزمون نرات 
• 9 اثربخشى واقعيتدرمانى مبتنى بر نظريئ انتخاب بر صميمت زناشويى

موجب فاصله كيرى زوجين مىشود؛ درحالى كه تلاشنكردن

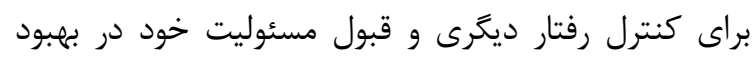

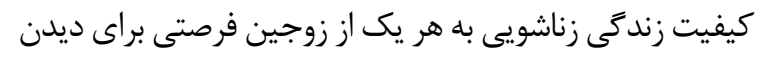

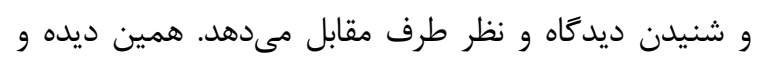

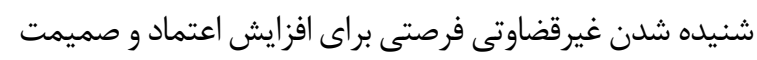

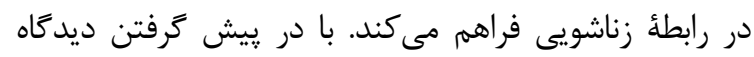

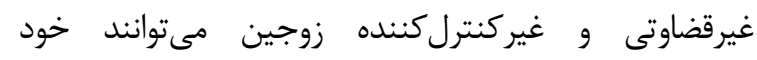
واقعىشان، نيازها و خواستههاى خود را با يكديكر مطرح كنند؛

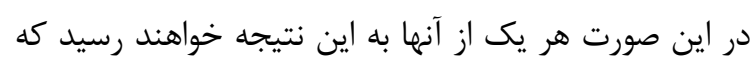

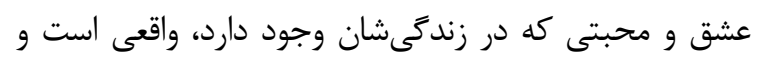

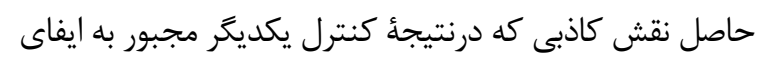

آن بودند، نيست [11]

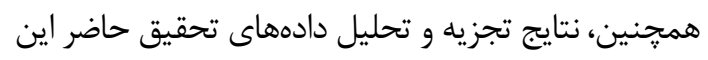

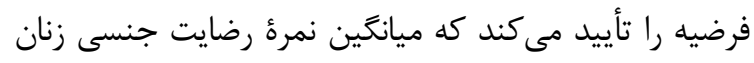

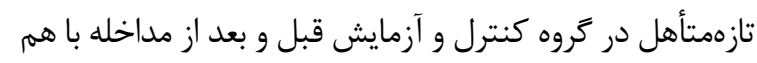

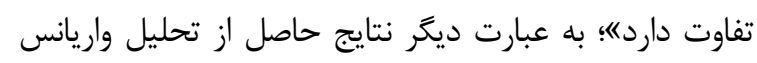

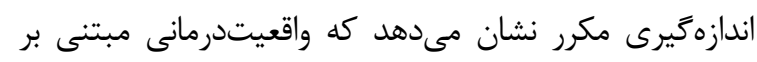

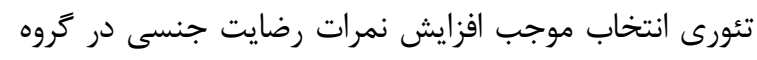

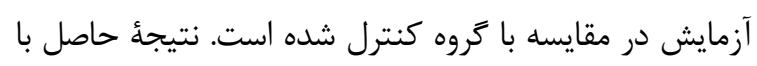

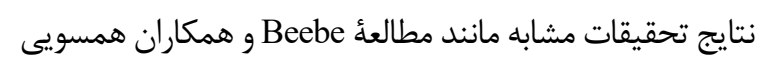

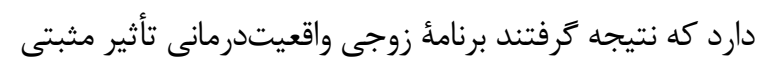

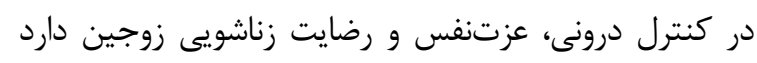

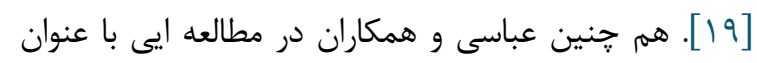

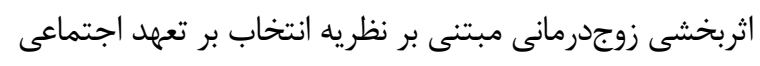

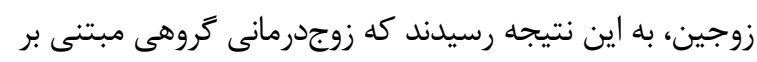

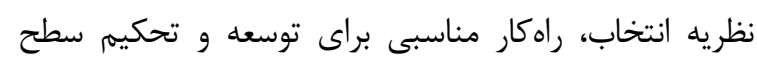

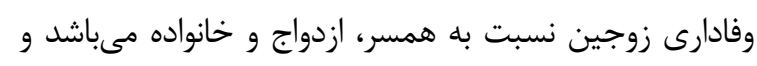

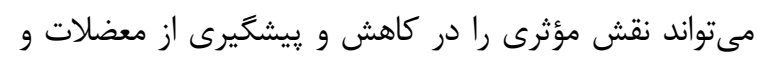

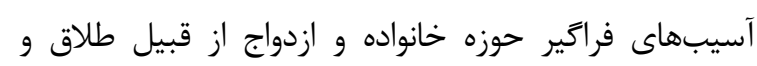

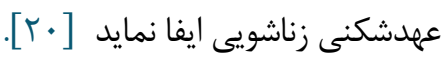

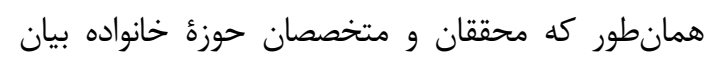

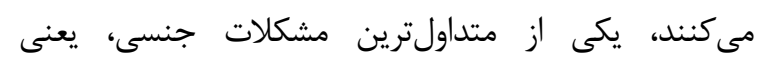

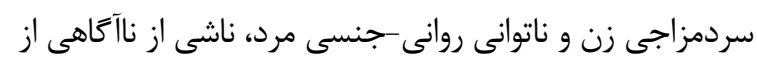

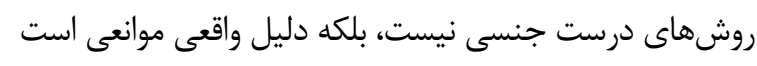

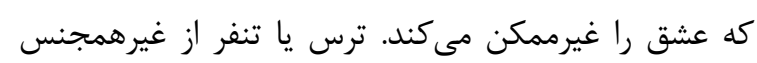

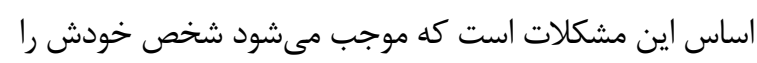

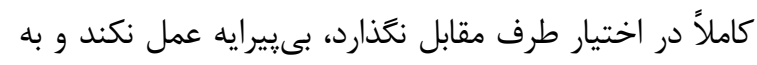

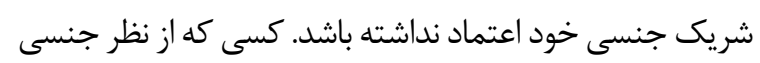

كروه كنترل و آزمايش قبل و بعد از مداخله با هم تفاوت دارد؛

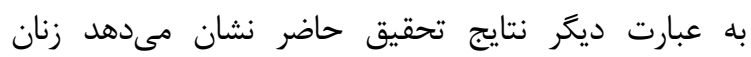

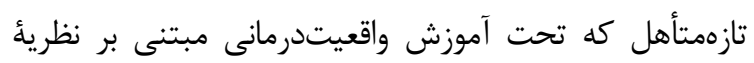

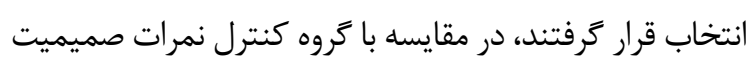

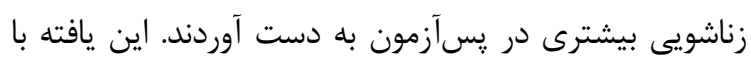
نتايج تحقيقات مشابه در اين زمينه مانند مطالعأ فتح الله زاده و همكاران [11] همسو است. آنها نتيجه كرفتند كه مدابن مداخلئ غنىسازى زندكى زناشويى براساس نظريئ انتخاب با اصلاح و و

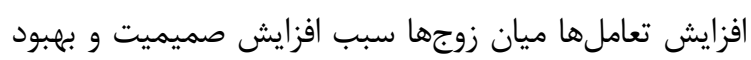

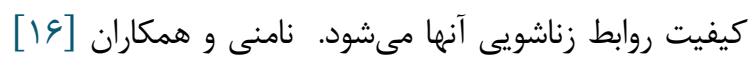

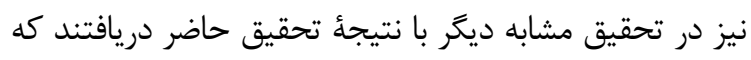

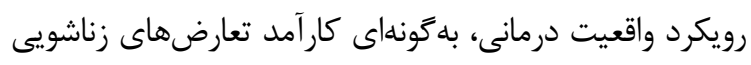

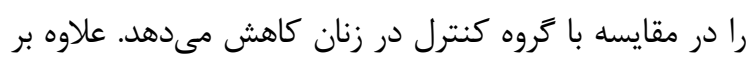

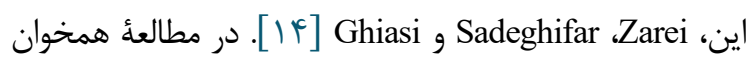
ديخر با نتيجه تحقيق حاضر به اين نتيجه رئه رسيدند كه مشاوره

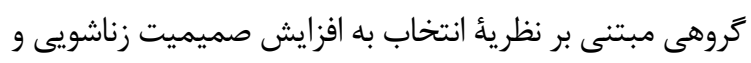
رضايت زناشويى و كاهش تعارضات زناشويى در زنان متأهل

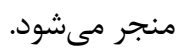

در تبيين اثربخشى واقعيتدرمانى بر افزايش صميمت

زناشويى زوجين تازمتأهل اشاره به اين كفتته

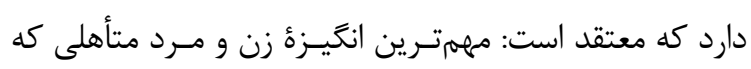

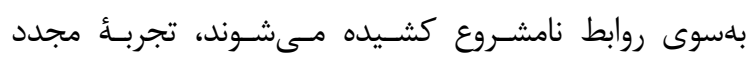

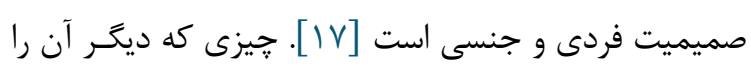

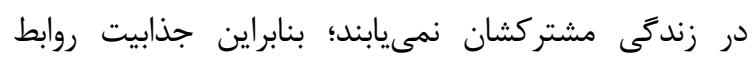

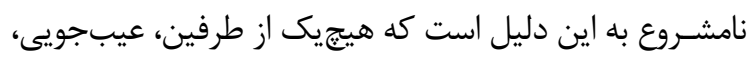

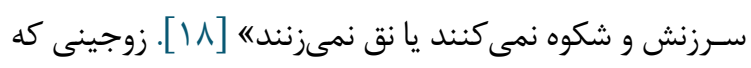
بهجاى توجه به نيازهاى يكديكر درصدد كنترل رفتار يكديكر

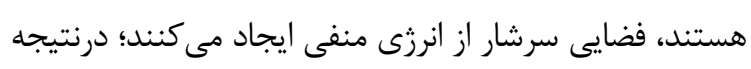

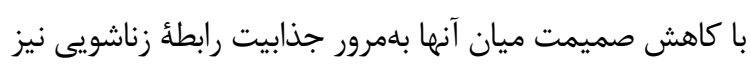

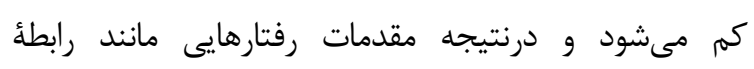

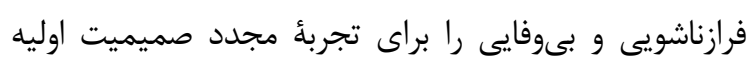

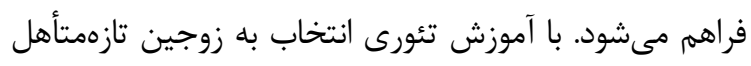

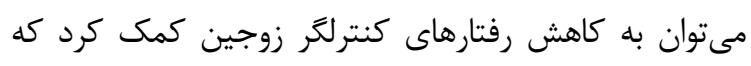

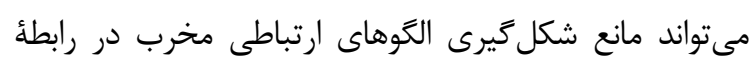

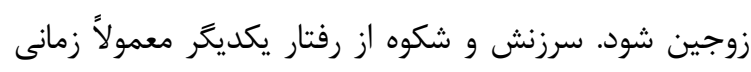

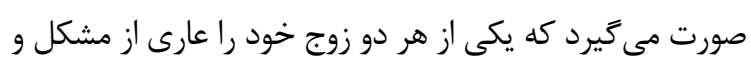

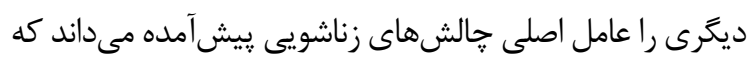

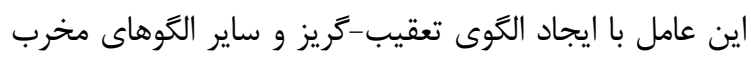


مى گيرد كه موجب افزايش صميميت بين زوجين مىشود و

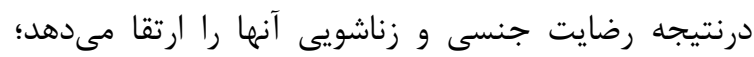

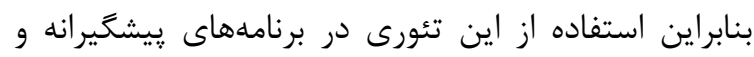

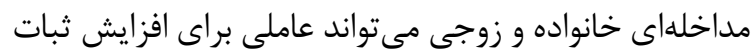
زندگى هاى زناشويى باشد.

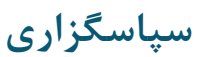

محققان بر خود لازم مىدانند كه از همكارى مراكز

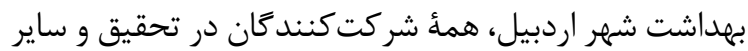
افرادى كه ما را در انجام هرجه بهتر اين تحقيق يارى كردند،

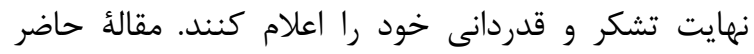

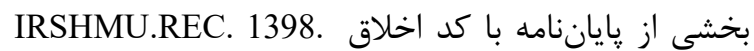
028 است كه با حمايت مالى معاونت تحقيقات و فناونه باون دانشگاه علوميزشكى شاهرود انجام شده است.

$$
\text { تعارض در منافع }
$$

بين نويسندكان هيج گونه تعارضى در منافع وجود ندارد

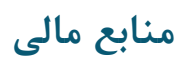

منابع مالى اين مطالعه توسط نويسندكان تامين شده است.

\section{References}

1. Carr A. Family therapy and systemic interventions for child-focused problems: the current evidence base. Journal of Family Therapy. 2019 Apr;41(2):153-213. [DOI:10.1111/1467-6427.12226]

2. Bagarozzi DA. Enhancing intimacy in marriage, Branner-Rouledye, Tylor \& Forancis group.

3. Crawford M, Unger R. Women and gender: A feminist psychology. McGraw-Hill; 2004.

4. Blume TW. Becoming a family counselor: A bridge to family therapy theory and practice. John Wiley \& Sons; 2006 Mar 31.

5. Byers ES, Wang A. Understanding Sexuality in Close Relationships From the Social Exchange Perspective.

6. Nichols NB, Backer-Fulghum LM, Boska CR, Sanford $\mathrm{K}$. Two types of disengagement during couples' conflicts: Withdrawal and passive immobility. Psychological assessment. 2015 Mar;27(1):203. [DOI:10.1037/pas0000045] [PMID]

7. Træen B, Štulhofer A, Janssen E, Carvalheira AA, Hald GM, Lange T, Graham C. Sexual activity and sexual satisfaction among older adults in four European countries. Archives of sexual behavior. 2019

$$
\begin{aligned}
& \text { دجار منع شده و مورد قضاوت قرار گرفته است، اگر بتواند خود } \\
& \text { را از ترس يا تنفر برهاند و درنتيجه در عشق ورزيدن توانا شود، } \\
& \text { مشكلات جنسى وى نيز حل خواهد شد، اما جنانجه نتواند } \\
& \text { هرجه در روابط جنسى آزموده باشد بى حاصل است [1/]]. }
\end{aligned}
$$

$$
\text { نتيجه گَيرى }
$$

هدف تحقيق حاضر مطالعه اثربخشى واقعيت درمانى

مبتنى بر نظريأ انتخاب بر صميمت زناشويى و رضايت جنسى

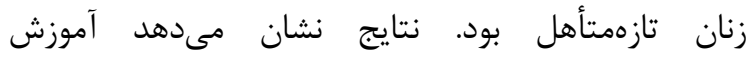
واقعيتدرمانى مبتنى بر نظرئُ انتخاب در زنان تازهمتأهل، رضايت جنسى و صميميت زناشويى در اين گروه را افزايش

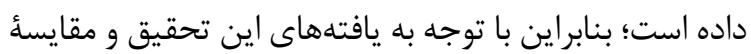

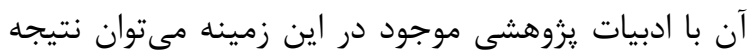

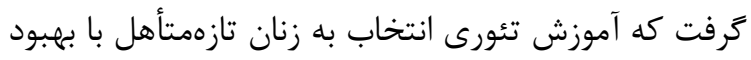

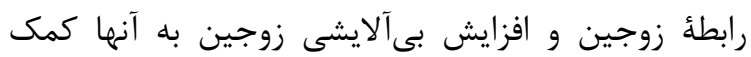

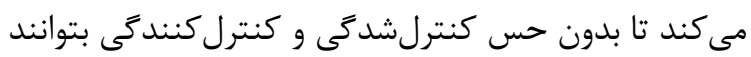
خود واقعىشان باشند؛ درنتيجه با افزايش اعتماد زوجين به

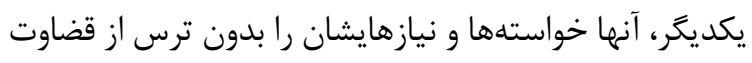
و طردشدن ابراز مى كنند كه همين عامل سبب مى ئود آنها

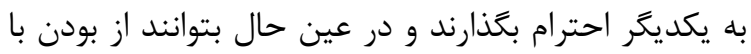

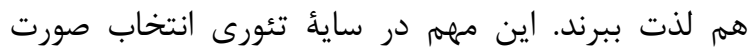

Apr 1;48(3):815-29. [DOI:10.1007/s10508-018-1256x] [PMID]

8. Nappi RE, Cucinella L, Martella S, Rossi M, Tiranini L, Martini E. Female sexual dysfunction (FSD): Prevalence and impact on quality of life (QoL). Maturitas. $2016 \quad$ Dec 1;94:87-91. [DOI:10.1016/j.maturitas.2016.09.013] [PMID]

9. Moridi H, Kajbaf MB, Mahmoodi A. Study the Effectiveness of Glaser's Reality Therapy on Couples' Marital Satisfaction, Life Satisfaction, and Communication Skills. Armaghane danesh. 2019 Dec 10;24(5):1013-27.

10. Weisner K, Marshall M. Using a discipline system to promote learning. Phi Delta Kappan. 2004 Mar;85(7):498-507.

\section{[DOI:10.1177/003172170408500707]}

11. Fathollahzadeh N, Mirsaififard LS, Kazemi M, Saadati $\mathrm{N}$, NavabiNejad S. Effectiveness of marital life enrichment based on Choice Theory on quality of marital relationship and couples' intimacy. Journal of Applied Psychology. 2017;11(3):43.

12. Elsayed, F. Elyas, E. The Effectiveness of a Counseling Program Based on Reality Therapy to Improve Marital Adjustment among Emotionally

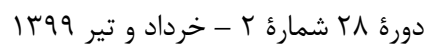


Separated Saudi Wives. Sylwan, 2016; 160(4): 343362.

13. Davoodvandi M, Shokouh Navabi Nejad VF. Examining the effectiveness of gottman couple therapy on improving marital adjustment and couples' intimacy. Iranian journal of psychiatry. 2018 Apr;13(2):135.

14. Zarei E, Sadeghifar E, Ghiasi F. A Study of Effects of Teaching Resiliency to Spouses of the War-Disabled on Marital Adjustment and Intimacy. Academic Journal of Psychological Studies. 2014;3(1):63-71.

15. Ziaee T, Jannati Y, Mobasheri E, Taghavi T, Abdollahi $\mathrm{H}$, Modanloo M, Behnampour N. The relationship between marital and sexual satisfaction among married women employees at Golestan University of Medical Sciences, Iran. Iranian journal of psychiatry and behavioral sciences. 2014;8(2):44.

16. Nameni E, Heydari H, Fatoorchi S. The Effectiveness of Combining Reality Therapy and Logo Therapy Approaches on the Quality of life and Psychological Adjustment of Female Householders.. Applied Psychological Research Quarterly 201 9, 10(1), 83-96

17. Tanguy L, Hetru O, Langlois A, Harvey PD. Characterization and Minimization of Glaser Competitive Homocoupling in Sonogashira Porphyrin-Based Polycondensation. The Journal of organic chemistry. 2019 Feb 22;84(6):3590-4. [DOI:10.1021/acs.joc.8b02596] [PMID]

18. French JE, Altgelt EE, Meltzer AL. The implications of sociosexuality for marital satisfaction and dissolution. Psychological science. 2019 Oct;30(10):1460-72. [DOI:10.1177/0956797619868997] [PMID]

19. Beebe JE, Robey PA. The prevalence and psychological impact of bullying on adolescents: An application of choice theory and reality therapy. International Journal of Choice Theory and Reality Therapy. 2011 Apr 1;30(2):33-44.

20. Abbasi H, Ahmadi S A, Fatehizadeh M, Bahrami F. Effect of Couple Therapy Based on the Choice Theory on Social Commitment of Couples . J Educ Community Health. 2017; 4 (2) :3-10URL: http://jech.umsha.ac.ir/article-1-298-en.html [DOI:10.21859/jech.4.2.3]

21. Kajbaf, M. (2008). The Psychology of Sexual Behavior (Theories and Views). Tehran: Psycho. 